\title{
Building a scientific attitude for Islamic elementary school students on Science Education learning based on science technology and society approach
}

\section{Sulthon}

IAIN Kudus, Jawa Tengah, Indonesia

sulthon52@gmail.com

DOI: 10.18326/mudarrisa.v10i1.73-98

\begin{abstract}
The objectives of this study are to describe the practice of Science Education (IPA) learning at Islamic Elementary School (MI) and to develop the model based on Science Technology and Society (STS/STM) for building certain scientific attitudes. The qualitative approach was employed by searching data on the implementation of IPA learning through direct observation. The data are then analyzed descriptively. The results show that: 1) Science Education learning model based on Science Technology and Society gives students opportunity to conduct IPA process correctly and apply mutual relationship between IPA concept, technological progress, and life in society through five stages: invitation, exploration, explanation, consolidation of concepts or follow-up, and assessment; 2) Science Education learning model based on Science Technology and Society can build a scientific attitude and behavior of students to be sensitive, have a curiosity attitude, attitudes of proof, flexible attitude, critical attitude, caring attitude towards living creatures and environment, objective, honest, open, and cooperative. To strengthen and solidify the building process of this scientific attitude, it is conducted with a variety of relevant madrasa (school) activities through the habituation of activities beyond programmed science learning which include: building clean living habits in the madrasa environment; building park; performing reforestation; and fostering environmental sensitivity through community service programs in the village environment.
\end{abstract}

Keywords: scientific attitude, learning science education, science technology and society 


\section{INTRODUCTION}

Environment is a place where human beings live life, without environment, human will not live, because human in fulfilling the necessities of life depends on the environment, such as water, air, soil, and the pattern of life in it. As the word of God in Qs. Al-Ghaafir, 40: 64, "Allah is the one who made the earth for you a place of residence and the sky as the roof ....". Thus the environment in which we live in the form of a stretch of land upon which the heavenly heavens is laid is prepared for human life. The purpose of God created nature is for the prosperity of human life, so as our gratitude and our responsibility to the natural environment as a place of human foothold must be preserved so that it is not easily destroyed for the sake of human survival.

But in reality, humans often perform acts that actually affect the destruction of the natural environment such as, indiscriminate logging, littering, seawater contamination, the excavation of the soil so that it destroys the soil structure, excessive use of hasprey resulted in ozone destruction, global warming as due to greenhouses, and so on. This natural destruction is getting worse due to human acts that are less responsible, either caused by human behavior itself, or due to the use of technology. Indeed, it is explicitly warned by Allah in Qs. Al-A'raf, 7:56 which mentions, "And do not corrupt the earth after it was created well ....". The above verse from the beginning has given a warning to humans to protect the environment and not make damage on land and in the oceans, then why is the natural damage that humans do always happen?. 
From various literature studies conducted, it was found that the occurrence of natural damage done by humans is mostly caused by: 1) the low knowledge and understanding of Science Education; and 2) the lustful nature of human greed, humility, and selfishness in life that always exploits nature and does not consider the long-term impact of this destruction of nature.

The current natural damage is already in conditions that threaten human life such as: ozone depletion, global warming, environmental pollution, water, air (air pollution), floods, forest fires, landslides, waste that endanger population growth, energy crises, coastal abrasion , acid rain, uncontrolled population growth and destruction of some ecosystems (Sitiatava Rizema Putra, 2013: 152). The current natural damage can not be allowed continuously, but immediate efforts for improvement are made through proper science education for students in madrasa or school. Education has the potential to play a great role in building the values, culture, and civilization for the better future by building students' scientific attitude, embedded scientific attitude to these students which will eventually give birth to a more independent generation figure and build a good attitude and able to maintain the environment well too.

IPA learning has in essence a tangible contribution in preparing for the life of the student in the future. Because the essence of IPA is a science that has a special characteristic that is studying natural phenomena both factual fact/event based on experiment (induction), and developed based on the theory (deduction). IPA as a process of scientific work and 
scientific products contains knowledge in the form of factual knowledge, conceptual, procedural knowledge, and cognitive meta knowledge (Sulthon, 2016).

Collette \& Chiappetta (1994: 33-41) states the essence of IPA consists of three dimensions: IPA as a method of thinking includes curiosity, imagination and desire to understand the phenomenon so as to be confident and judge to answer questions and solve problems. IPA as the method of investigation includes the desire to understand nature through experimentation, observation, hypothesis and validity as knowledge from representative disciplines such as facts, concepts, principles, laws, theories and specific models for the material of science. This means that the teaching and learning process of IPA should contain all three dimensions of IPA. IPA is a body of knowledge that has been tested, which can be expressed in the form of a set of general principles (Sulistyorini, S \& Supartono, 2007: 9-10).

The implications of teaching are to reflect the nature of IPA by doing IPA activities involving students in observation, measurement, calculation, hypothesis formulation, data collection, data interpretation and research or always involving them in the IPA process (Liem, 2007: xv) . The skills of the IPA process will equip students with the skills: 1) making observations; 2) putting forward the hypothesis; 3) interpretation; 4) designing experiments; 5) conducting investigations; 6) drawing conclusions; 7) prediction; 8) application; and 9) communicating the results (Semiawan, C. 1992: 17). With the IPA process, skills will build 
students' scientific attitude. The development of students' scientific attitude is very important to help develop positive attitudes in students. These scientific attitudes include: curiosity, attitude to always prioritize proof, flexible attitude towards new ideas, critical contemplation and sensitivity toward living things and the environment (Samatowa, U. 2016: 97-98).

But in reality many teachers and the implementation of IPA lessons are less aware and understand it, so many of them are less concerned and tend to underestimate. Consequently the quality of science lessons in schools is not maximally pursued. Many teachers in science lessons do not give students the opportunity to be creative, active and innovative. This is because the teachers do not understand and understand about the nature of IPA learning.

Currently many IPA teachers are less mastering IPA as an empirical science, lacking a sense of empathy in IPA teaching, IPA taught never started with the question what or how things happen, and the question of IPA why and the limited ability of IPA teachers to lead lab work in IPA because of IPA as empirical-experimental science, so most IPA teachers in teaching simply convey the facts without knowing what and integrate the IPA and mere recitation. (Insani, M. D., 2016).

With regard to IPA teaching that is merely a memorization of memorization or teaching with a conveying system, students will not have direct experience of the real nature that will be useful in their life (Djohar 1996: 19). A hands-on experience in IPA learning will integrate the 
abstract student experience with the real conditions. Learning by doing will strengthen children's memory, direct experience plays an important role as a driver of the pace of cognitive development of children. The direct experience of the child occurs spontaneously, efficiently, and depends on the consistency between the relationship of method and object to the level of cognitive development. Hegemony of science learning that always give priority to rote cause IPA does not develop maximally and many experience crisis (Samatowa, U., 2006: 12).

IPA lessons in Madrasa (schools) that lack sufficient adaptation of the nature of the IPA leads to learning only to present the material contained in the curriculum and textbooks. Students learn only for the sake of repetition and examination and regardless of the problems in everyday life. IPA learning materials are perceived as a burden that must be remembered, memorized, and understood and not perceived meaning for everyday life. So the students' scientific attitude is low. Less awakening of this scientific attitude as a result of science lessons that have not been in accordance with the nature of IPA is mostly done by teachers because less mastering science in learning. Therefore it is very important to build the scientific attitude of MI students through science learning based on Environmental Science and Society. Therefore, this research becomes interesting to be continued, to know how Science Education learning model based on Science Technology and Society at MI, and how to build students' scientific attitude on Science Education learning model based on Science Technology and Society. 


\section{Mudarrisa: Jurnal Kajian Pendidikan Islam, Vol. 10, No. 1, 2018}

\section{METHODS}

This study uses a qualitative approach by searching data, organizing, sorting data, synthesizing, searching and finding important patterns, and concluding them (Moleong, 2006: 248). The data collected is then analyzed in two steps: 1) pre-field analysis, ie analyzing preliminary data as a foothold to focus the research, it will develop after field research, 2) data analysis in the field, by collecting data which take place in field to ensure that data is credible, complete, and saturated (Sugiyono, 2005: 276). Next do data reduction, data presentation, and data verification.

\section{DISCUSSION}

\section{Science Technology and Society Learning Model}

Talking about the problem of learning model can not be separated from the knowledge about the style used by teachers in learning. A model is a representation of an actual process that allows a person or group of people to try to act on that model. Model is an interpretation of the results of observations and measurements obtained from several systems (Agus Suprijono, 2016: 64). While learning literally means the process, the ways, the actions of learning, and the actions of making people or living beings learn. Learning is a process or effort to create learning conditions in developing the ability of interests and talents of students optimally, so that competence and learning objectives are achieved (Prastowo, A. 2013: 57).

Learning is a way of organizing students to achieve educational goals that manifest changes in individual behavior caused by learning 


\section{Mudarrisa: Jurnal Kajian Pendidikan Islam, Vol. 10, No. 1, 2018}

experiences, where behavioral changes are relatively persistent cognitive, affective, or psychomotor (Putra, S. R. 2013: 15). Based on the above description, it can be concluded that learning is a poses interaction of learners with educators in a learning environment to achieve learning objectives is the change of behavior both cognitive, affective, and psychomotor that is sedentary.

According to Joyce \& Weil in Rusman (2013: 133) states that, the learning model is a plan or pattern that can be used to design long-term learning plans, design learning materials, and guide learning in the classroom or outside the classroom. Learning model is a plan or a pattern used as a guide in planning the learning in the classroom or learning in the tutorial. Learning model refers to the learning approaches to be used, including instructional goals, stages in learning activities, learning environments, and classroom management (Trianto, 2015: 51).

The learning model is the basis of the learning practice resulting from the reduction of educational psychology theory and learning theory designed based on an analysis of curriculum implementation and its implications on the operational level in the classroom. the learning model can be interpreted as the pattern used for curriculum development, organizing the material, and giving instruction to the classroom teacher (Suprijono, A. 2015: 64-650). Can be abstracted that the model of learning is all series of presentation of teaching materials covering all aspects before, is, and after the learning done by the teacher and all the facilities related directly or indirectly in the learning process. 
Science Technology and Society is an IPA learning model that is oriented towards the concepts and principles of science, technology, and society. STM learning model is more applying the continuity relationship between the concept of IPA which led advances in technology that is very useful in human life, but the development of technology is also not neutral from the emergence of natural damage, therefore IPA, Technology and Society must have mutual care, attention and support. The targets to be achieved by the learning model of STM is to increase students' interest in science and to form personal students who understand the science and technology. Furthermore, students as citizens are more responsible for their natural and social environment (Sadia, I. W., 2014: 46). Setiatava Rizema Putra (2015: 41), stated that STM is one of the approaches of contextual learning that can help the students to make more meaningful lessons. Because the STM approach is related to real life, students have feelings, concerns, wills, memories, and thoughts that change through life experiences.

STM is a learning model that develops cognitive, affective, and psychomotor abilities that are fully formed within the individual as a student with the expectation to be applied in everyday life (Poedjiadi, A., 2007: 124). STM Province according to The National Science Teachers Association (NSTA) is learning and teaching science in the context of human experience (Putra, S. R., 2013: 140-141).

While Poedjiadi in Putra, S.R., (2013: 141) Son said that STM means using technology as a liaison between the IPA and the community. 
The STM learning model is a translation of science technology and society approach (STS). Learning science technology and society is the application of a reciprocal relationship between the right IPA planting which will then give birth to technological progress that is friendly or able to maintain environmental sustainability. The unification of technology and environmental science will build and improve the state of the natural environment better.

Understanding science and technology means that there must be the ability to solve problems by using science concepts, recognizing existing technologies in society and their impacts, being able to use and maintain technological, creative and simple technological results, as well as to make decisions based on values apply in society (Sitiatava Rizema Putra, 2013: 142).

From the above description it can be understood that the understanding of the STM learning model is a model of learning that unites between IPA, technology, and society that emphasizes the concepts, theories, and principles of the framework with the application of technology and familiar IPA issues with problems in the community. In relation to the model of Community Science Science, so that more details will be described about the characteristics of learning STM, goals, and syntax.

\section{Characteristics of Science Technology and Society Learning Model}

Learning Science, technology and society has special characteristics that must be done in learning among others; determine problems, utilize the potential of the community, students actively explore information, focus 
on the problems of science and technology and society, process skills, selfawareness planting, sensitivity and learning awareness. This is as described below: 1) identification of the problem; 2) use of local resources; 3) the participation of students actively seeking information; 4) extension of study outside the classroom and school; 5) focus on the impact of science and technology; 6) A view that the content of IPA is not just a concept that must be mastered by students; 7) Emphasis on process skills; 8) Emphasis on career awareness; 9) Opportunities for students to act as citizens; 10) Identification of science and technology impacts the future; 11) Freedom or autonomy in the learning process (Sitiatava Rizema Putra, 2013: 143-144).

In general, IPA based on science, technology and society is more emphasized on the concept of IPA and then the process of IPA, and produce IPA products and scientific attitude. Through the application of learning based on the nature of science, it will build the emergence of attitudes that build self-awareness to preserve this nature. The characteristics of STM learning include: 1) having sufficient knowledge about facts, concepts and theories; 2) in making day-to-day decisions using the concept of IPA, science process skills, and IPA values; 3) recognizing the advantages and limitations of science and technology; 4) knowing the source of the IPA; 5) anticipating the negative impact of IPA. 6) distinguish scientific evidence and personal opinion. 7) having a positive attitude towards the IPA (I Wayan Sadia, 2014: 39). 
Based on the above description, the characteristics of the STM learning model, namely: 1) learning model that begins with the issue that becomes the main characteristic; 2) by raising the issue, students are encouraged to seek answers or solve problems caused by the issue; 3) when solving problems, students will seek information from a variety of sources, not just in the classroom, but outside the classroom, in various ways, including using technology; 4) so that students learn to discover and compile their own knowledge gained from the learning process it does; 5) In addition, the learning process is also an opportunity for students to participate as citizens.

\section{Objectives of Science Technology and Society Learning Model}

STM learning has an urgent purpose that there are at least three objectives namely; 1) giving students the opportunity to be able to understand the concept of science through experiments or experiments; 2) providing a direct experience of the natural phenomena and the evolving technologies in people's lives; 3) leading to the impact of science, technology, and society. The objectives of the STM learning model are as follows: 1) More learning gives students the opportunity to compare and contrast IPA and technology, while appreciating the way in science and technology in contributing to new knowledge and influences; 2) Provide examples from the past and present on the enormous changes in the field of science and technology brought by the community; 3) Provide or offer a global view of science and technology relation to society, and show its impact on the 
development of the nation and the ecology of the earth (Sitiatava Rizema Putra, 2013: 158-159).

STM learning model built by improving science learning system by giving opportunity to student to do observation or experiment directly about natural phenomena which is investigated either happened at present, past and future by comparing the happening of changes caused by progress IPA, technology, and its impact on people's lives. Indirectly STM learning model will be achieved awareness, sensitivity, and scientific attitude because students experience a concrete learning and direct experience in everyday life.

The learning model of STM involves 5 (five) domains: 1) the realm of need for conceptual understanding, where students see the concept as personal needs; 2) the principle aspect as a science product that is the concept seen from its usefulness or necessity; 3) the realm of science process in the form of student learning with direct experience; 4) the realm of science skills ie students see the IPA process as the skills used to improve; 5) the domain of scientific attitude that is, students see the process of science as an important part of what they do (I Wayan Sadia, 2014: 38). The purpose of STM learning model are: 1) Effective for mastery of the concept in students. 2) Stages of application or application domains, students given the STM model demonstrate maximum ability in applying the concept of IPA in everyday life as well as showing its impact on awareness to keep the natural environment in order to remain sustainable. 


\section{Model syntax of IPA learning based on STM}

In practice, IPA lessons with the STM model emphasizes on the role of MI teachers, students' active roles, issues of IPA, technology and community, science and technology relationships, technological and community life relationships, and environmental issues, etc. The STM learning model consists of four phases: invitation phase, exploration, explanation and solution, and follow up; 1) In the invitation phase, teachers can assist students in exploring technological IPA issues in society, organizing ideas, and articulating them briefly; 2) In the exploration phase, students learn in small groups that have been prepared beforehand, to explore various information in the form of facts, concepts and scientific principles; 3) In the explanatory and solution phases students can construct the various problems discussed in small groups to rearrange the representation of the problem; 4) In the follow-up phase, students try to find creative ideas from small groups to find solutions in anticipation of the consequences of alternative actions (I Wayan Sadia, 2014: 46-47).

In addition to the implementation of the STM-based IPA learning model above there is a different conceptually but equally applicable, that is in learning starting from; 1 . Introduction. This stage, students are invited to discover and explore the problems that arise in society such as air pollution, landslide, global worming, hotter air, air pollution, and so on. This stage is also called initiation or initiation, initiation and invitation, ie an invitation to focus students on learning; 2) Concept formation. At this stage, students are invited to observe; put forward hypothesis; interpret; 


\section{Mudarrisa: Jurnal Kajian Pendidikan Islam, Vol. 10, No. 1, 2018}

designing experiments; conduct investigations; draw a conclusion; predict; application; and communicate results, at this stage can be done through various approaches and methods; 3) Application of the concept, which provides opportunities for students to apply the results or IPA products in the form of principles, concepts, propositions that can be applied in life; 4) Consolidation of concept. At this stage, students are given the opportunity to present their group results to other groups to be analyzed in more depth, consolidating the concept through emphasis in the study materials; 5) Rating (Sitiatava Rizema Putra, 2013: 154-155).

Based on the above description, it can be concluded that the synt STM there are 5 stages: 1) Invitation; 2) Exploration; 3) Explanation; 4) Stabilization of concepts or follow-up; and 5) Assessment. All stages in the implementation, will form the concept of science, science process skills, produce IPA products, and will further develop students' scientific attitude, namely the emergence of awareness, sensitivity, belonging, keeping, and responsible for the environment where students live. Furthermore, students can explore solutions in a problem that is assisted by the formation of concepts and consolidation of the concept.

\section{Scientific Attitude}

Attitude is a state that exists within a person that causes the occurrence of a behavior (Tri Dayakisni \& Hudaniah (2012: 79) .The attitude is a tendency to act or react to stimuli. As attitude is a relationship that is interconnected with the behavior, then the attitude has components that are at least three ie cognitive, affective, and conative components. 


\section{Mudarrisa: Jurnal Kajian Pendidikan Islam, Vol. 10, No. 1, 2018}

Cognitive components are concerned with the understanding and knowledge of an object that belongs to a person, while the affective component is associated with pleasure or displeasure, this is an evaluation of the value system observed The conative component is related to behavior as a relation to the object of its attitude (Tri Dayakisni, 2012: 80).

Scientific attitude is an attitude that must be possessed by a scientist in doing research and communicate the results of his research (Ahmad Susanto, 2015: 169). Scientific attitude is a manifestation of the character values developed in the science lesson (Dwi Fujiani, 2013: 5). There are nine aspects developed from scientific attitude in science learning, that is: curiosity, want to get something new, cooperative attitude, not despair, not prejudiced, introspective, responsible, free thinking, and self-discipline (Ahmad Susanto , 2015: 169-170).

Scientific attitudes are attitudes that every student must have in doing his job to learn to continue, reject or accept and alter or add to a science. Scientific attitudes are developed through student activities in science learning during discussions, experiments, simulations, and project activities in the field. Scientific attitudes that need to be developed further in science learning include curiosity, attitude to always prioritize (respect for evidence), flexible attitude, critical reflection, and caring attitude to living things and environment (Usman Samatowa, 2006: 97-98). Scientific attitude includes skeptical, critical, sensitive, objective, honest, open, true, and able to cooperate (Trianto, 2015: 143). 
Children of primary school age or primary school between the ages of 6 or 7 years to 11 or 12 years are children who are in the cognitive development of the concrete operational phase. The phase that characterizes the curiosity is high enough to recognize the environment. Therefore, in science learning should be given concrete experiences and opportunities to develop the ability to think and behave towards nature, so that will arise awareness to understand, maintain, and preserve nature as well (Susanto, 2015: 168-170).

In relationship between the components of attitude and scientific attitudes that are built in IPA lesson in MI, there will be realization of understanding and science about IPA and to bring a sense of pleasure or displeasure, the emergence of behavior as a relationship response attitude curiosity attitude, attitude to always put the evidence, flexible attitude toward new ideas, critical contemplation, and caring attitude toward living things and the environment. Thus, the awakening of scientific attitude toward the students of science in IPA learning with STM model will build the attitude and behavior of students as a manifestation of their curiosity about nature, caring attitude, pleasure, and behave to preserve and preserve this natural environment with full obligation and responsibility. IPA (Science Education)

Science comes from English word. The word "science" comes from the Latin word "scientia" which means I know. "Science" consists of social science (IPS) and natural science. But in its development science is often translated as IPA which means Natural Science only (Trianto, 2015: 136). 
IPA is a systematic collection of knowledge and in its use is generally limited to natural phenomena. Its development is not only characterized by the existence of a collection of facts, but by the existence of scientific method and scientific attitude (Trianto, 2015: 136). IPA is one of the main subjects in the curriculum of education in Indonesia, including at elementary school level. IPA is the human effort in understanding the universe through proper observation of the objectives, and using the procedure, and is explained by reasoning to get a conclusion (Susanto, A. 2015: 166-167). While Nokes in Aly. A, \& Rahma, E. (2014: 21) states that IPA is theoretical knowledge obtained by a special method. Thus it can be understood that IPA is a branch of science that studies natural phenomena through observation, systematic experiments, and is explained with the help of rules, laws, principles, theories and hypotheses.

Jacobson \& Bergman in Susanto, A. (2015: 166-170) says that IPA has characteristics that include: 1) IPA is a collection of concepts, principles, laws, and theories; 2) Scientific processes can be physical and mental, and look at natural phenomena, including their application; 3) Attitude of determination, curiosity, and diligence in uncovering the secrets of nature; 4) Science cannot prove all but few or a few; 5) The truth of IPA is subjective rather than objective truth. For Triyanto (2015: 153) IPA is concerned with how to systematically find out about nature so that science is not only a collection of knowledge in the form of facts, concepts or principles but also the process of discovery. 
The characteristics of IPA are collection of concepts, principles, laws, and theories, which examine the natural phenomenon with an attitude of determination and the truth is subjective. Specifically IPA has fungi and goals include: 1) Inculcating belief in God Almighty. 2) Developing skills, attitudes and scientific values. 3) Preparing students to become IPA-responsive citizens and technology. 4) Mastering the concept of science for the provision of living in society and continuing education to a higher level (Trianto, 2015: 138).

According to Susanto, A. (2015: 171-172), as for the purpose of IPA teaching in elementary school in the National Board of Education Standards is intended to: "1) Acquire belief in the greatness of God Almighty. 2) Develop knowledge and understanding of IPA concepts. 3) Developing curiosity and positive attitude. 4) Develop process skills. 5) Raise awareness to participate in maintaining, preserving and preserving the natural environment. 6) Raise awareness to respect nature. 7) Obtain knowledge supplies, concepts, and science skills as a basis for continuing education to junior high. The nature of IPA can be classified into 3 parts: IPA as a product, process and scientific attitude. IPA is also a procedure and science as well as technology. However, this addition is the development of the IPA as a product, process and attitude, namely the development of procedures from the process, while the technology of application of concepts and principles of IPA as a product (Desstya, A., 2015). 
The nature of IPA can be classified into 4 parts, namely: "Science as knowledge that studies and investigates natural phenomena that is empirical, IPA as a process or method and product, IPA can be considered as application, IPA can be considered as a means to develop certain attitudes and values (Putra, SR, 2013: 51-52). The essence of IPA is built on the basis of scientific products, scientific processes and scientific attitudes. IPA is also viewed as a process, as a product, and as a procedure (Trianto, 2015: 137-138). Thus the nature of IPA is not only as a product, process and attitude alone, but also as an explanation of natural phenomena with all aspects of the empirical nature, as well as an application capable of developing the discipline of science by using technology.

Relationship among IPA, technology and society

In the world of Science Education, it will always be done various studies, research, observations, and experiments. To produce IPA products, from this IPA product will develop technology, with technology, it will change life, mindset, customs, cultural values, and civilization (Nurdin, 2009: 123 136). IPA and technology have a reciprocal relationship, that technology depends on IPA products, whereas IPA scientists in the process of investigation are in desperate need of technological assistance. Due to technological assistance, IPA scientists can conduct investigations more accurately and more quickly in an effort to find new IPA products. IPA is growing more rapidly due to technological assistance and technology is developing as a result of new IPA products. So scientists are quicker and 
more accurate in their search for scientific facts, concepts and principles (Ngafifi, M., 2014: 33-47).

Technologies bring about changes in lifestyle, politics, religious and human welfare. IPA products contribute to the welfare of mankind. IPA as a process, giving people the capacity to think to solve problems (Sadia, I. W., 2014: 33). IPA and technology must be able to overcome problems, using IPA concepts, understand existing technologies in society and their impacts, and be able to use and maintain simple technology results that are useful in people's lives (Putra, S. R., 2013: 142). Thus the relationship of science, technology and society is that, technology as a link between science and society. IPA as a process, making people think to solve problems. Human needs as individuals and as citizens of society, provide a strong impetus for the development of science.

Building the Scientific Attitude of MI Students Through IPA Learning STM will improve science skills and build scientific attitude of students will then form a caring attitude, honest, maintain and protect the environment and so on, essentially the emphasis of the STM learning pattern is to develop the relationship between scientific knowledge possessed by students with their daily experience (Santi, DK, 2014). STM learning uses the concepts and principles that apply to constructivist models in learning, giving students the opportunity to be environmentally responsible, creative, and capable of performing as decision makers in solving problems ". (Kariawati, S., 2017). The relationship of STM with scientific attitude of student by learning IPA based on STM, is that it can 


\section{Mudarrisa: Jurnal Kajian Pendidikan Islam, Vol. 10, No. 1, 2018}

develop student's scientific knowledge and daily experience and become environmentally and environmentally responsible person (Astuti, R., Sunarno, W. \& Sudarisman, S., 2016). In developing the scientific attitude of MI students based on the results of observation and interviews with the madrasa in this research is through various activities of consolidation and application of what has been studied in IPA as IPA process and followed up with the program activities as a form of scientific attitude in science that includes:

Establish clean living habits in the Madrasa environment

Clean culture in the school environment is always enforced in this MI, ranging from throwing garbage, playing, buying snacks and eating always put into effect to always be responsible for cleanliness. School yard is always guarded from garbage and water so it always looks clean. Every once a week the madrasa bathrooms and toilets must be cleaned alternately between classes IV, V, and VI. Supervised by his homeroom teacher. All these cultures are always under the supervision of the classroom teacher. This is in accordance with the process of behavior formation that is fully determined by rules, predictable, and controllable, behavioral changes in a student's self can be done through conditioning (Nahar, N. I., 2016). This means that habituation is done to form a sedentary behavior that becomes character and personality.

Building Madrasa Park

Park building is a manifestation of loving plants; the application of the beauty of the school, the school environment is a miniature of the 
arrangement of the park that must be realized by the students as a proof of love for beauty. Creating a garden is part of the attitude of building a beautiful environment and loving plants. With parks built, there will be obligations to keep, keep the plants not to die and provide fertilizer and watering. The existence of efforts to keep this park is a habit of concern for the environment and become a laboratory for students to build a soul like to keep the environment and responsible with nature.

Reforestation in Madrasa

Greening schools is part of the application of a sense of preserving the environment and instilling a sense of desire to maintain environmental balance. Reforestation is a banana from the conscious of a beautiful and sustainable environment. What needs to be emphasized on the students is the awareness to restore the soil structure and maintain the balance of the environment is the existence of plants. Plants except to keep the soil from the threat of floods and landslides also add shade and oxygen producer.

Environmental Sensitivity through community service programs Including madrasa program in building students' scientific attitude is to involve students in the activities of cleaning the village environment where the madrasa is located. By requiring students every Friday morning to follow the work of cleaning the waterways and cleaning up the environment closest to the madrasa. This environmental sensitivity is implanted in the child to become a habit and an integral part of social sensitivity or part of the form of preserving the environment. 


\section{CONCLUSION}

Based on the discussion described in the preceding chapters, some points can be concluded: firstly, Science Education learning model based on Science Technology and Society is an IPA learning model that provides students with the opportunity to conduct the IPA process correctly and implements mutual relationships between IPA conceptualization, technological advancement, and life in society. The unification of science, technology, and society in IPA learning happens through five stages: 1) Invitation; 2) Exploration; 3) Explanation; 4) Stabilization of concepts or follow-up; and 5) Assessment.

The second point that can be concluded is that IPA learning model based on Science Technology and Society can build students' scientific attitude and behavior to be sensitive, have an attitude of curiosity, attitudes of proof, flexibility, critical attitude, caring attitude towards living creature and environment, objective, honest, open, and cooperative. To strengthen and solidify the building of scientific attitude, it is carried out with a variety of relevant madrasa activities through the habituation of activities beyond programmed IPA learning which include: 1) Establishing clean living habits in the madrasa environment; 2) Building madrasa park; 3) Reforesting madrasa; and 4) Growing sensitivity to the environment through community service programs in the village environment.

\section{REFERENCES}

Aly, A. \& Eny, R. (2014). Ilmu Alamiah Dasar. Jakarta: Bumi Aksara. 
Astuti, R., Sunarno, W. \& Sudarisman, S. (2016). Pembelajaran IPA dengan Pendekatan Ketrampilan Proses Sains menggunakan Metode Eksperimen Bebas Termodifikasi dan Eksperimen Terbimbing Ditinjau dari Sikap Ilmiah dan Motivasi Belajar Siswa. Proceeding Biology Education Conference. 13 (1). 338-345.

Collette, A. T., \& Chiappetta, E. L. (1994). Science instruction in the middle and secondary schools. New York: Macmillan Publishing Company.

Dayakisni, T. \& Hudaniah. 2012. Psikologi Sosial, Malang: UMM Press.

Desstya, A. (2015). Keterampilan Proses Sains Dan Pembelajaran IPA di Sekolah Dasar; Telaah Buku Siswa Kelas Iv Sd Tema 2 Karya Sumini. Journal Profesi Pendidikan Dasar. 2 (2). 95 - 102.

Djohar. (1996). Reformasi pendidikan IPA. MIPA. 1 (2). 19-25.

Darmodjo, H. (1993). Pendidikan IPA, Jakarta: Depdikbud

Insani, M. D. (2016). Studi Pendahuluan Identifikasi Kesulitan dalam

Pembelajaran Pada Guru IPA SMP Se-Kota Malang. Jurnal Pendidikan Biologi. 7 (2). 81-93.

Kariawati, S. (2017). Upaya Meningkatkan Hasil Belajar Siswa Pada Mata Pelajaran Ipa Materi Energi Dan Kegunaanya Dengan Menggunakan Kip Ipa Pada Siswa Kelas Iv Sd Negeri 18 Tongkuno. Pedagogika; Jurnal Ilmu Pendidikan. 8 (2). 125-306.

Moleong, J. L. (2006). Metodologi Penelitian Kualitatif, Bandung: Remaja Rosdakarya.

Nahar, N. I. (2016). Penerapan Teori Belajar Behavioristik Dalam Proses Pembelajaran. Nusantara, Journal Ilmu Pengetahuan Sosial. 1 (2). 64 74.

Nazir, M. (1998). Metode Penelitian. Jakarta: Ghalia Indonesia.

Ngafifi, M. (2014). Kemajuan Teknologi Dan Pola Hidup Manusia Dalam Perspektif Sosial Budaya. Journal Pembangunan Pendidikan; Fondasi dan Aplikasi. 2 (1). 33-47.

Nurdin. (2009). Pengembangan Pendidikan IPA Berbasis Teknologi Informasi Komputer. Jurnal Administrasi Pendidikan. 9 (1). 123-136.

Putra, S. R. 2013. Desain Belajar Mengajar Kreatif Berbasis IPA. Diva Press. Poedjiadi, A. (2007). IPA Teknologi Masyarakat Model Pembelajaran Konstekstual Bermuatan Nilai. Bandung: Remaja Rosdakarya. 
Poedjiadi, A. (2013). Sains teknologi masyarakat model pembelajaran kontekstual bermuatan nilai, Bandung: Rosdakarya.

Prastowo, A. (2013). Pengembangan Bahan Ajar Tematik. Yogyakarta: Diva Press.

Rusman. (2013). Model-Model Pembelajaran Mengembangkan Profesionalisme Guru. Jakarta: Rajawali Pers.

Samatowa. U (2016). Pembelajaran IPA di Sekolah Dasar. Jakarta: Permata Puri Media.

Santi, D.K. (2014). Peningkatan Keterampilan Proses Dan Hasil Belajar IPA Menggunakan Model Pembelajaran Sains Teknologi Masyarakat (Stm) Pada Siswa Kelas VI Sdn 1 Kalinanas Wonosegoro. Scholaria. 4 (3). 122-131.

Sadia. I. W. (2014). Model-Model Pembelajaran IPA Konstruktivistik. Yogyakarta: Graha Ilmu.

Semiawan, C. (1992). Pendekatan Keterampiln Proses, Jakarta: Gramedia Widiasarana Indonesia

Sugiyono. 2005. Metode Penelitian Pendidikan, Bandung: Alfabeta.

Sulistyorini, S. \& Suparton. (2007). Model pembelajaran IPA Sekolah Dasar dan Penerapannya dalam KTSP. Yogyakarta: Tiara Wacana.

Sulthon. (2016). Pembelajaran IPA yang Efektif Dan Menyenangkan Bagi Siswa Madrasa Ibtidaiyah (MI). Elementary. 4 (1). 38-54.

Suprijono, A. (2016). Cooperative Learning Teori dan Aplikasi PAIKEM. Yogyakarta: Pustaka Pelajar.

Susanto, A. (2015). Teori Belajar dan Pembelajaran di Sekolah Dasar. Jakarta: Prenadamedia Group.

Trianto. 2015. Model Pembelajaran Terpadu. Jakarta: Bumi Aksara.

Usman, H. \& Akbar, P.S. (2006). Metodologi Penelitian Sosial. Jakarta: Bumi Aksara.

Wiyani, N. A. (2013). Desain Pembelajaran Pendidikan. Yogyakarta: Ar-Ruzz Media. 